\title{
PROBABILITY THEORY AND
}

MATHEMATICAL STATISTICS 



\section{Volume II}

\section{PROBABILITY THEORY AND MATHEMATICAL STATISTICS \\ Proceedings of the Fourth Vilnius Conference}

Vilnius, USSR, 24-29 June 1985

Edited by

Yu. V. Prohorov, V. A. Statulevicius,

V. V. Sazonov and B. Grigelonis

Utrecht, The Netherlands 
VNU Science Press BV

P.O. Box 2093

$3500 \mathrm{~GB}$ Utrecht

The Netherlands

\section{(C) 1987 VNU Science Press BV}

First published 1987

All rights reserved. No part of this publication may be reproduced, stored in a retrieval system, or transmitted, in any form or by any means, electronic, mechanical, photocopying, recording, or otherwise, without the prior permission of the copyright owner.

\section{CIP-DATA KONINKLIJKE BIBLIOTHEEK, DEN HAAG}

Probability theory and mathematical statistics:

proceedings of the Fourth Vilnius Conference: Vilnius, USSR, 24-29 June 1985/ed. by Yu.V. Prohorov . . . [et al.] - Utrecht: VNU Science Press. - I11.

ISBN 90-6764-068-9 (vol. II)

ISBN 90-6764-069-7 (set)

SISO 517 UDC 519.2(063)

Subject headings: probability theory/mathematical statistics. 